\title{
51. Thick Limestones of the Upper Carboniferous- Permian Age in Japan; An Interpretation of Their Mode of Deposition
}

By Hisakatsu YABE, M.J.A. (Comm. April 12, 1958)

There are many limestone masses of the Upper CarboniferousPermian age in several places of Japan, to enumerate a few examples: the Yayamadake limestone of the Kuma Mountainland in Kyûsyû; Akiyosi limestone in the Tyûgoku region; Ibukiyama limestone in the Kinki region; Akasaka, Itinotani, and Ômi limestones in central Honsyû. These $400-500 \mathrm{~m}$, seldom even over $1000 \mathrm{~m}$ thick limestone masses are apparently massive in most cases, rarely exhibiting more or less distinct stratification. The zoning of these limestones are possible only by means of the fusulinids they contain, and recent studies by many students of fusulinids disclosed that all or most of the fusulinid zones, from the Millerella zone up to the Yabeina-Lepidolina zone, are represented in regular succession within these limestones.

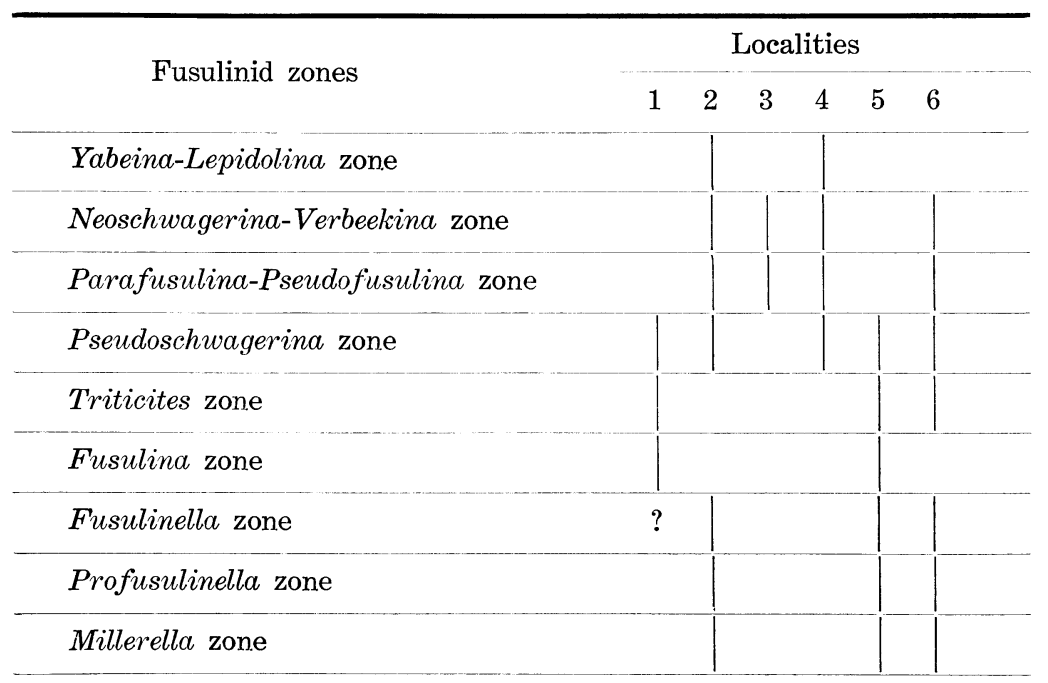

1. Yayamadake limestone, Kuma Mountainland, Kyûsyû

2. Akiyosi limestone, Tyûgoku region, Honsyû

3. Ibukiyama limestone, Kinki region, Honsyû

4. Akasaka limestone, central Honsyû

5. Itinotani limestone, Hida Plateau, central Honsyû

6. Ômi limestone, Hida Plateau, central Honsyû

Certain fusulinid zones are occasionally missing in those limestone masses as the annexed table shows, and where they are missing, there 
are often found limestone-breccias with round to subangular fragments of limestone derived from various earlier fusulinid zones. The breccias also contain free individuals of fusulinids, some nearly perfect and others more or less broken, in the matrix; the youngest types of the foraminifers are suggestive of the geological age of the limestonebreccias themselves. Oolitic structure is sometimes present. Where fusulinids are crowded, other organisms are almost excluded, and where the former are rare, corals, brachiopods, molluses, etc. are common. Very rarely, brachiopods or molluses of extraordinary large sizes were found in particular horizons of black, earthy sapropelic limestone (I. Hayasaka, 1925, 1933, 1953), which reminds the present writer of sapropel deposits of mangrove swamps in tropical lands.

In general, these limestone masses are almost free from clastic materials of terrestrial origin, except for the occasionally interbedded slate and "schalstein"-submarine basic volcanic ejecta, mostly finegrained material, but not seldom in association with lava-agglomerate. The non-calcareous substances, if present, are rather negligible in their total amount, except near the base, where the limestone and schalstein are frequently alternated, and eventually these pass downward to the basal schalstein.

It is striking that these limestone masses accumulated under a certain quite uniform condition on the gently subsiding, but otherwise stable sea floor through the long duration of the Upper Carboniferous and Lower Permian, i.e. perhaps for some $40 \times 10^{6}$ years, only rarely affected by negative shifting of the sea-level as indicated by the omission of one or two fusulinid zones due to either non-deposition or abrasion, and by limestone breccias probably produced by destructive wave-action. In many aspects, these ancient limestone accumulations recall the coral or algal reefs of the present day. Most probably the limestone accumulations were built on submarine mounds of volcanic material, risen above the general level of the surrounding sea-floor.

There is no evidence known to the writer in support of the view that these limestone masses are mere remnants of a once continuous, thick limestone sheet of vast extent so as to cover a considerable area of southwestern Japan, and separated to their present state by subsequent tectonic disturbances and repeated denudation. On the contrary, they seem to have been formed originally as isolated patches in situ, since they are surrounded by contemporaneous non-calcareous sedimentary formations which not seldom have thin limestone beds or small lenses in approaching them. The fusulinids of these interbedded limestone lenses or beds are similar to those of the respective fusulinid zones of the limestone masses nearby, which are the main bodies. 


\section{References}

I. Hayasaka (1925): On some Paleozoic molluses of Japan, 1, Lamellibranchiata and Scaphopoda, Sci. Rep., Tohoku Imp. Univ., 2nd ser. (Geology), 8, no. 2.

- (1933): On the Upper Carboniferous Brachiopoda fauna from the Nabeyama region, Totigi Prefecture, Japan, Mem. Fac. Sci. Agr., Taihoku Imp. Univ., Taiwan, 22, no. 1.

I. Hayasaka and S. Hayasaka (1953): Fossil assemblages of molluses and brachiopods of unusually large sizes from the Permian of Japan, Trans. Proc. Paleont. Soc. Japan, N. S., no. 10. 